\title{
Hardness of finger nails in well-nourished and malnourished populations
}

\author{
BY J. R. K. ROBSON \\ Nutrition Program, School of Public Health, \\ The University of Michigan, Ann Arbor, Michigan 48104, USA \\ (Received 26 November 1973-Accepted 4 February 1974)
}

I. The Knoop test of hardness applied to samples of finger nails from 334 healthy and 147 malnourished individuals showed statistically significant differences in the mean hardness of the nails of the two groups.

2. The hardest nails were those of Filipino infants and children suffering from proteinenergy deficiency. The softest nails were those of children in Guatemala recovering from protein-energy deficiency. Ranking of hardness appeared to be related to the severity and duration of protein-energy depletion.

3. In children up to I 2 years of age, hardness did not appear to be influenced by the age, sex, and racial origins of individuals or the environmental conditions to which nail specimens were exposed.

4. Further studies are required to correlate hardness with clinical, biochemical and anthropometric measurements of nutritional status during protein-energy deprivation and during recovery. The causes of the differences in hardness need to be explored.

The chemical composition and structure of human nails is known to alter both in disease and malnutrition (Sibinga, 1959; Leonard, Morris \& Brown, 1968). As a result, changes might be expected in the physical characteristics of this integument.

The Knoop test of hardness has been used to test the hardness of human nail. In a preliminary study the range of hardness values was found to be small in healthy infants, children and adults. In malnourished children the range was large and in general the nails were harder than those from healthy persons (Robson \& El Tahawi, I97I).

The Knoop hardness test has now been applied to a larger sample of nails from two groups representing well-nourished and malnourished populations.

\section{EXPERIMENTAL}

\section{The sample}

Samples were grouped into two categories. The first category comprised nails collected from 334 children of European and Negroid origins; this sample was designated 'normal'. The physical appearance of all of these children was apparently healthy and they were considered to be well-nourished. All of them were regularly attending an elementary school in the Ypsilanti School District of Washtenaw County, Michigan. Any child with growth disturbance (including obesity), a current health problem, or an illness within 6 weeks prior to the examination, serious enough for him to miss school, was excluded from the study. All of the subjects were above the 3 rd 
Table $\mathrm{x}$. Characteristics of subjects providing samples of finger-nail clippings

$\begin{array}{llll}\text { Group } & \text { Subgroup } & \text { No. Age range } \\ \text { Normal } & - & 334 & 5^{-12} \text { years }\end{array}$

Malnourished Failure to thrive $20 \quad 5$ months -7 years

Acute illness

9 I month-5 years

Phenylketonuria $54 \quad 5$ days -7 years

Kwashiorkor

(recovery)

Kwashiorkor and 30 i I months-6 years marasmus

Secondary
malnutrition i6 Adults
Characteristics

Apparently healthy, well-nourished, above 3 rd percentile for height and weight. Caucasian and Negroid origins.

Failure to achieve 3 rd percentile for height and weight. No obvious pathology present, and adequate diet available. Clinical diagnosis of 'failure to thrive'. Caucasians and Negroids.

Suffering from acute illness, hospitalized for treatment. Clinical diagnosis included viral pneumonia, acute otitis media, pyrexia of unknown origin. Caucasians and Negroids.

Confirmed diagnosis of phenylketonuria. All cases under dietary treatment. Caucasians.

I8 I5 months -7 years Kwashiorkor diagnosed. All cases under treatment were in recovery stage and in care of Rehabilitation Centre in Guatemala.

Fifteen diagnosed as kwashiorkor, fifteen as marasmus. All Filipinos admitted to hospital. Samples taken on admission.

Suffering from malnutrition secondary to malabsorption syndrome. Caucasians.

percentile for height and weight as judged by the Iowa Standards (Stuart \& Meredith, 1946). Their ages ranged between 5 and 12 years.

The second sample, designated 'malnourished', comprised nails collected from I3I infants and children suffering from a variety of conditions which were judged to have affected their nutritional status. The sample included nails from eighteen children recovering from kwashiorkor in rehabilitation centres in the city of Guatemala. It also included specimens from thirty cases of marasmus and kwashiorkor admitted to the National Children's Hospital, Quezon City, Philippines. There were also nails from children diagnosed as 'failure to thrive' in the Washtenaw County Well Baby Clinic at Ypsilanti, Michigan. Children acutely ill in Detroit General Hospital were used as a source for the nails in the subgroup designated 'acute illness'. The cases of phenylketonuria were from various locations in Michigan, but they were all under surveillance in the University Hospital. Also included in this group were nails from sixteen adults suffering from secondary malnutrition. The characteristics of the subjects providing samples of nails to the two groups are shown in Table I.

\section{Method}

All specimens had been removed from the left middle finger by either nail clippers or scissors. Specimens from overseas were placed in small paper envelopes and immediately airmailed to the laboratory. On receipt, all these specimens and those 
Table 2. Knoop hardness numbers for finger nails* from groups of normal and malnourished individuals. Malnourished subgroups are ranked in order of hardness

Sample

All nails

All normals

All malnourished

Kwashiorkor (recovery)

Acute illness

Secondary malnutrition

Phenylketonuria

Failure to thrive

Marasmus

Kwashiorkor

\begin{tabular}{|c|c|c|c|c|}
\hline $\begin{array}{c}\text { No. } \\
\text { in sample }\end{array}$ & $\begin{array}{c}\text { Mean } \\
\text { hardness }\end{array}$ & SD & $\mathrm{SE}$ & Range \\
\hline 497 & 18.44 & 5.27 & 0.23 & $5.40-95 \cdot 60$ \\
\hline 334 & 17.80 & $4 \cdot 46$ & 0.24 & $5 \cdot 40-63 \cdot 10$ \\
\hline 147 & r9.01 & $5 \cdot 4 \mathrm{I}$ & 0.44 & $7 \cdot 66-95 \cdot 60$ \\
\hline 18 & 13.59 & $2 \cdot 22$ & 0.52 & $10 \cdot 73-18.80$ \\
\hline 9 & 13.63 & $3 \cdot 87$ & $1 \cdot 29$ & $7 \cdot 66-18 \cdot 90$ \\
\hline 16 & ז7.39 & $4 \cdot 34$ & 1.08 & II $76-24 \cdot 90$ \\
\hline & 18.79 & 3.88 & 0.52 & $10.13-25.33$ \\
\hline 20 & 20.74 & $3 \cdot 83$ & 0.85 & $13.36-29 \cdot 40$ \\
\hline I 5 & $22 \cdot 06$ & $2 \cdot 60$ & 0.67 & $17 \cdot 90-27 \cdot 96$ \\
\hline I 5 & 25.83 & $7 \cdot 94$ & 2.05 & $16 \cdot 43-95 \cdot 60$ \\
\hline
\end{tabular}

* Robson \& E1 Tahawi (197r).

collected locally were mounted in phenolic resin. The embedded nails were polished and subjected to the Knoop test of hardness of materials as described previously (Robson \& El Tahawi, 1971). Three hardness readings were taken at different sites on each nail clipping, and they were converted to Knoop hardness numbers from a standard conversion table after each measuring session.

\section{Statistical analysis}

The results were coded and punched onto IBM punch cards and processed by the MIDAS (Michigan Interactive Data Analysis System) computer program. The results were treated as a whole and by subgroups. A one-way analysis of variance was applied to test the hypothesis that the group means were equal. Two-sided cornparisons were made using Dunnett's procedure (Steel \& Torrie, 1960).

\section{RESULTS AND DISCUSSION}

The means, standard deviations, standard errors of the means, and ranges of hardness of the groups and subgroups are shown in Table 2. Differences in the mean Knoop hardness numbers of nails from the normal and malnourished groups were significant $(P<0.01)$.

The mean hardness of the normals was compared with each of the malnourished subgroups. The hypothesis that the normal and subgroup means were equal was rejected in favour of the alternative of unequal means $\left(\mathrm{F}_{7473}=13.752, P<0.0005\right)$. Dunnett's procedure provides for paired comparisons (normals $v$. malnourished groups). Seven comparisons were made at an over-all level of significance of $5 \%$ $(\alpha=0.05)$. Significant differences were found between the means of hardness for the normal group and the malnourished subgroups designated 'failure to thrive', 'kwashiorkor (recovery)', 'acute illness', 'kwashiorkor', and 'marasmus'. There were no significant differences between the normal group and the malnourished subgroups designated 'secondary malnutrition' and 'phenylketonuria' (see Table 3 ).

The observed differences could have been due to a number of factors. First, consideration has to be given to variations inherent in the methodology. Thus, variability 
Table 3. Significance of difference in means of hardness of nails from normal and malnourished subgroups

$\begin{array}{lccc}\begin{array}{c}\text { Comparison of } \\ \text { normal v.: }\end{array} & \begin{array}{c}\text { Difference } \\ (\bar{x}-\bar{x} \\ \text { normal })\end{array} & \begin{array}{c}\text { Dunnett } \\ \text { allowance } \\ (0.5)^{*}\end{array} & \text { Significance } \\ \begin{array}{l}\text { Failure to thrive } \\ \text { Kwashiorkor } \\ \text { (recovery) }\end{array} & 2.9659 & 2.7585 & + \\ \text { Secondary } & -4.1916 & 2.7956 & + \\ \quad \text { malnutrition } & -0.38537 & 2.9556 & - \\ \text { Phenylketonuria } & 1.0068 & 1.6934 & - \\ \text { Acute illness } & -4.1462 & 3.9009 & + \\ \text { Marasmus } & 4.2789 & 3.0490 & + \\ \text { Kwashiorkor } & 8.0545 & 3.0490 & +\end{array}$

- If the mean difference exceeds \pm the Dunnett allowance, the difference is declared significant.

in the hardness-testing machine, variations in the technique, and errors in computing the hardness numbers could influence the results. In view of the large numbers in the sample, the reliability of the test, the known accuracy of the hardness-testing machine and the experience of the technician, these factors were not considered to be responsible for the observed differences. Another possible extrinsic influence on nail hardness was the effect of the environment over the passage of time.

Twenty nails from the normal group selected at random were examined twice at an intcrval of ro months. Differences in hardness did not, in any sample, exceed the range of hardness found in multiple measurements on a single nail. Two other possible causes of the differences in hardness were considered. First, there were differences in the age structure of the subjects in the malnourished and normal groups. The effect of age on hardness was assessed from frequency distribution diagrams plotting age against hardness for all samples from subjects under 12 years of age (normal and malnourished) and normal subjects under 12 years of age. The distribution of the plots was random and did not suggest any relationship between hardness, or softness, and age up to 12 years of age. It is possible that, after puberty, sex differences and occupational and degenerative effects are likely to influence hardness.

The effect of different environments on the hardness of normal nails has not been evaluated. All the normal nails were collected in the temperate midwestern United States, whereas all the hard nails were from children suffering from kwashiorkor or marasmus in the tropics. The soft nails of children recovering from kwashiorkor suggests that location did not determine hardness. Differences in hardness attributable to the varying racial and sex structure of the individuals supplying the samples could not be completely discounted since no samples were measured from 'normal' Filipino or Guatemalan Indian children. But, when the mean hardness of samples from males and females and from Blacks and Caucasians were compared, no significant differences in hardness were found between the two sexes and the two ethnic groups.

The ranking of mean hardness suggests that this property is related to the duration and severity of protein or energy deprivation, or both. Thus, the hardest nails were found in children with kwashiorkor and marasmus; there was no statistical difference 
Table 4. Changes in nail hardness during recovery from disease

\begin{tabular}{|c|c|c|c|c|c|}
\hline Case & Diagnosis & Sex & Date & Hardness* & Body-wt (kg) \\
\hline A & 'Short bowel' & o & $\begin{array}{l}\text { Sept. I971 } \\
\text { Nov. I } 971 \\
\text { Mar. } 1972 \\
\text { May } 1972 \\
\text { July I } 972\end{array}$ & $\begin{array}{l}20 \cdot 8 \\
21 \cdot 6 \\
12 \cdot 4 \\
13 \cdot 8 \\
13.4\end{array}$ & $\begin{array}{c}54 \cdot 7 \\
- \\
- \\
63 \cdot 1\end{array}$ \\
\hline B & 'Nontropical sprue' & q & $\begin{array}{l}\text { Sept } 1971 \\
\text { Nov. } 1971\end{array}$ & $\begin{array}{l}20 \cdot 0 \\
12 \cdot 8\end{array}$ & $\begin{array}{l}35^{-8} \\
35 \cdot 8\end{array}$ \\
\hline
\end{tabular}

in the means of hardness numbers to suggest a possible method of differentiating these two forms of protein malnutrition. The softest nails were those of Guatemalan children recovering from kwashiorkor. All of these children had been given adequate amounts of good-quality protein during rehabilitation. It has been noted previously that nails became softer during recovery (Robson \& El Tahawi, 197I); these results show that the nails of the recovering Guatemalan children were significantly softer than normal. The mean hardness of the remaining subgroups, namely those suffering from phenylketonuria and chronic disease, was not significantly different from the means of the normal group. The numbers in the acute illness group were very small, however, and this sample may not be representative. Furthermore, the children with acute illness were all from a very poor part of Detroit where undernutrition is known to exist. All of the children with phenylketonuria had been under the care of a specialized unit and they were under dietary control, making satisfactory clinical progress.

The cases in the chronic disease category were also under treatment. One of these was an adult male with malnutrition secondary to a surgically-induced short bowel. Over a period of 8 months his weight increased from $54 \cdot 7$ to $63 \cdot \mathrm{rgg}$. A second subject in this group was a $35.8 \mathrm{~kg}$ adult female with nontropical sprue who showed a marked clinical improvement over a period of 2 months. The increasing softness of the nails of these two subjects is shown in Table 4. No trends in hardness were observed in nine subjects with phenylketonuria whose nails were examined every 4 weeks over a period of 12 weeks.

The mean hardness of the malnourished group was lower than the values previously reported by Robson \& El Tahawi (1971). In the earlier study the mean values for hardness in groups of malnourished infants and children were $32 \cdot 21,34.48$ and 34.09 respectively. The mean for 147 samples from the malnourished group in the present study was weighted by low values from the Guatemalan children recovering from malnutrition, as well as others whose clinical condition was not serious. The lower values could have been due also to the use, in all instances, of the $25 \mathrm{~g}$ stylus impression weight. In the earlier study stylus weights varying between $25 \mathrm{~g}$ and $100 \mathrm{~g}$ had been used.

In conclusion, statistically significant differences were noted in the hardness of samples of finger nails from normal and malnourished groups. The hardest nails were found in Filipino infants and children, the softest nails were found in Guatemalan 
children recovering from kwashiorkor. The results support the hypothesis that up to I2 years of age at least, hardness of nail is an index of nutritional status, but further investigations are required to correlate nail hardness with clinical, anthropometric and biochemical measurements in subjects with protein-energy deficiency. These subjects should be selected from different environments and comparisons should be made during the acute stages of the disease and in recovery.

Further study is required also to determine the cause of the differences observed. Mineral deficiencies including those of iron and zinc may have co-existed with malnutrition suggesting the need for chemical examination of nails in health and disease.

This study could not have been possible without the help of a number of colleagues and I wish to express my appreciation to them. They include Dr Ivan Beghin of the Institute of Nutrition for Central America and Panama for his help in providing specimens from Guatemala, and Dr Crisanta de Joya-Agregado, who provided specimens from patients in the National Children's Hospital, Quezon City, Philippines. Dr A. B. French and Dr R. J. Allen kindly arranged for the periodic collection of specimens from their patients in the University Hospital. The Tukon hardness tester was made available by Professor W. C. Bigelow of the Department of Materials and Metallurgical Engineering, College of Engineering. Mr George Brooks of the same department devoted much of his own time to supervising the measurement of the specimens. Mr James Bursick of the Department of Biostatistics, School of Public Health assisted in the statistical testing of the results. The research was supported by Contract No. HSM 2I-71-535, Department of Health, Education and Welfare, Center for Disease Control, Atlanta, Georgia.

\section{REFERENCES}

Leonard, P. J., Morris, W. P. \& Brown, R. (1968). Biochem. f. 110, 2,2 P.

Robson, J. R. K. \& El Tahawi, H. D. (1971). Br. F. Nutr. 26, 233.

Sibinga, M. S. (1959). Pediatrics, Springfield 24, 225.

Steel, R. G. D. \& Torrie, J. H. (1960). Principles and Procedures of Statistics p. I I . New York: McGrawHill.

Stuart, H. C. \& Meredith, H. V. (1946). Am. F. publ. Hlth 36, ${ }_{3} 6_{5}$. 